\title{
Peran "Teologi Sosial" Gereja Protestan Indonesia Di Gorontalo (GPIG) Dalam Menanggapi Masalah Kemiskinan
}

\section{The Role of "Social Theology" of the Indonesian Protestant Church in Gorontalo (GPIG) in Responding to the Problem of Poverty}

\author{
Rudy Harold $\left.{ }^{1}\right)^{*}$ \\ ${ }^{1)}$ Universitas Negeri Gorontalo \\ *) Penulis korespondensi: rudy_harold@ung.ac.id
}

\begin{abstract}
Abstrak
Artikel ini bertujuan untuk menelaah teologi sosial yang berkembang di lingkungan Gereja Protestan Indonesia di Gorontalo (GPIG) dalam menanggapi masalah kemiskinan dan ketidakadilan sosial. Data yang dianalisis bersumber dari pemikiran-pemikiran teologis, baik yang diartikulasikan oleh perorangan (pendeta, guru Agama, penatua, diaken) maupun pemikiran teologis dan sikap GPIG sebagai satu lembaga agama sebagaimana yang dicerminkan dalam hasil-hasil persidangan dari tingkat jemaat hingga sinodal. Berdasarkan hasil penelitian, teologi sosial yang dikembangkan di GPIG dalam menanggapi masalah kemiskinan bersumber dari refleksi teologi GPIG tentang gereja (eklesiologi) dan keselamatan (soteriologi). Hal ini berdasarkan kajian terhadap dokumen - dokumen Tata Gereja GPIG tentang Pokok Panggilan dan Tugas GPIG serta pemahaman tentang keselamatan yang terkandung dalam Tata Gereja GPIG.
\end{abstract}

Kata Kunci: Teologi Sosial, gereja, keselamatan, GPIG, kemiskinan

This article aims to examine the social theology that is alive and thriving in the Indonesian Protestant Church in Gorontalo (GPIG) in response to the problem of poverty and social injustice. The data analyzed comes from theological thinking articulated by individuals (pastors, teachers of religion, elders, deacons) as well as theological thinking and attitudes of the GPIG as a religious institution, as reflected in the results of the trial of the congregational level to the sinodal level. Based on the research results, the social theology developed in the GPIG in response to problems of poverty, is sourced from GPIG theological reflection on the church (ecclesiology) and salvation (soteriology). It is based on a review of the Basic Rules of GPIG documents about the Principal Calling and Duties of the GPIG as well as an understanding of salvation contained in the Basic Rules of GPIG.

Keywords: Social Theology, church, salvation, GPIG, poverty

\section{Pendahuluan}

Wacana teologis tentang perlunya gereja terlibat dalam persoalanpersoalan masyarakat, kebudayaan, ekonomi dan politik sebenarnya sudah tidak lagi menjadi polemik. Stigma tentang gereja yang hanya 
memerhatikan perkara keselamatan manusia dari kebinasaan akibat dosa yang eskatologi sudah tidak lagi sering didengarkan dan ditujukan pada gereja-gereja. Sebagian besar denominasi gereja telah sepakat bahwa kekristenan yang mengabaikan konteks tidak dapat diterima lagi. Kontekstualisasi iman dan teologi kristen adalah suatu yang imperatif. ${ }^{1}$ Karena teologi kristen tidak akan bermanfaat tanpa memperhitungkan realitas-realitas yang menantang refleksi teologis itu sendiri. ${ }^{2}$

Teologi bukan hanya suatu studi intelektual dan akademis, yang mulai dari praduga-praduga teologi obyektif, tetapi suatu pengetahuan dan hikmat dalam suatu situasi konkret. Karena itu, teologi tidak dapat dilakukan di luar suatu konteks yang hidup, yang dalam rangka studi ini berarti situasi penderitaan bangsabangsa di Asia. ${ }^{3}$

Berbicara mengenai konteks, tentu ada sekian banyak realitas yang dapat dihubungkan dengan apa yang disebut dengan konteks dalam berteologi. Tapi dari sekian banyak realitas itu, kemiskinan mendapat perhatian khusus dalam perkembangan teologi kontekstual di negaranegara Asia. Alasannya tidak lain karena sebagian negara-negara Asia adalah miskin dan digolongkan sebagai negara-negara sedang berkembang. ${ }^{4}$

Fakta menunjukkan bahwa Provinsi Gorontalo 10 tahun yang lalu tepatnya tahun 2007 maka berdasarkan analisis SUSENAS pada tahun 2007, garis kemiskinannya ditetapkan sebesar Rp. 146.458- untuk daerah perkotaan sedangkan untuk daerah pedesaan sebesar Rp. 134.410,-. 5 Mengacu penghitungan garis kemiskinan tersebut, tingkat kemiskinan

${ }^{1}$ Stephen B. Bevans mengungkapkan ada dua kategori faktor yang mendasari pemikiran bahwa kontekstualisasi itu adalah suatu yang imperatif yakni faktor internal dan eksternal. Internal antara lain inkarnasi Kritus dan ciri sacramental dari realitas. Sedangkan faktor eksternal terdiri dari ketidakpuasan gereja-gereja di negera berkembang terhadap ketidaksesuaian pemikiran teologi negara Barat dengan keberadaan masyarakat dan budaya di negera-negara berkembang. Stephen B Bevans, Model-Model Teologi Kontekstual (Maumere, Flores: Ledalero, 2002), 13-25.

2 A. A. Yewangoe, Theologia Crucis di Asia: Pandangan-Pandangan Orang Kristen Asia Mengenai Penderitaan Dalam Kemiskinan Dan Keberagamaan Di Asia ( Jakarta: BPK Gunung Mulia, 2004), 9.

${ }^{3}$ A. A. Yewangoe, Theologia Crusis Di Asia: Pandangan-Pandangan Orang Kristen Asia Mengenai Penderitaan Dalam Kemiskinan Dan Keberagamaan Di Asia, 9.

${ }^{4} \mathrm{Hal}$ ini dapat dipertegas melalui pesan sidang Dewan Gereja-Gereja Asia pada tahun 1980 yang mengingatkan masyarakat Asia tentang kemiskinan sebagai masalah yang menimpa sebagian besar umat manusia di seluruh dunia. Yewangoe, 9.

${ }^{5}$ Boby Rantow Payu, "Analisis Kondisi Kemiskinan Absolut Prov. Gorontalo", Jurnal Pelangi Ilmu 3, No. 2 (September 2010):47, diakses 25 Februari 2017, http://repository.ung.ac.id/karyailmiah/show/149/analisis-kondisi-kemiskinan-absolutprovinsi-gorontalo.html. 
absolut di Gorontalo pada tahun 2007 adalah 40,22\%. ${ }^{6}$ Walaupun persentase jumlah masyarakat miskin di Gorontalo mengalami penurunan dari tahun ke tahun, namun tingginya persentase masyarakat miskin Gorontalo tersebut menempatkan Provinsi Gorontalo pada urutan keempat jumlah masyarakat miskin terbesar di Indonesia (peringkat pertama Prov. Papua, disusul Irian Jaya Barat, dan Maluku). Namun saat ini di tahun 2017, setelah 10 tahun berlalu, berdasarkan data terakhir yang dikutip dari Berita Resmi Statistik oleh Badan Pusat Statistik Provinsi Gorontalo, menyatakan bahwa survei pada Maret 2016 persentase penduduk miskin di Provinsi Gorontalo sebesar 17,72 persen. Angka ini turun dibandingkan persentase penduduk miskin September 2015, yaitu 18,16 persen. Berarti selama kurun waktu 6 (enam) bulan telah terjadi penurunan sebesar 0,44 persen. $^{7}$ Selama 10 tahun terlihat penurunan $22,50 \%$ yang artinya rata-rata terjadi penurunan $2,25 \% /$ tahun. Data terakhir menunjukkan penurunan yang relatif kecil 0,44\%/semester.

Apa yang perlu untuk mendapat perhatian sehubungan dengan gambaran Badan Pusat Statistik Provinsi Gorontalo tentang kemiskinan di Provinsi Gorontalo tahun 2016 yakni:

Bila dibedakan Garis Kemiskinan daerah perkotaan dan pedesaan, maka Garis Kemiskinan di Perkotaan pada Maret 2016 sebesar Rp284.308 per kapita per bulan, dan Garis Kemiskinan di Pedesaan sebesar Rp284.190 per kapita per bulan; I Selama kurun waktu 6 (enam) bulan, Indeks Kedalaman Kemiskinan (Pl) mengalami kenaikan dari 3,076 pada September 2015 menjadi 4,116 pada Maret 2016. Artinya jarak antara rata-rata pengeluaran penduduk miskin terhadap garis kemiskinan semakin lebar. ${ }^{8}$

Data tersebut di atas menunjukkan bahwa persoalan kemiskinan bukan hanya menjadi tanggung jawab pemerintah, namu juga merupakan tanggung jawab bersama dalam hal ini adalah tanggung jawab gereja di mana di dalamnya berhimpun orang-orang percaya sebagai pribadi.

Dalam gereja sendiri pemikiran dan praksis tentang kemiskinan sudah menjadi tema dalam pelayanan mimbar (khotbah), dan dimanifestasikan dalam pelayanan diakonia, namun masih sering dijumpai

${ }^{6}$ Boby Rantow Payu, "Analisis Kondisi Kemiskinan Absolut Prov. Gorontalo", Jurnal Pelangi Ilmu 3, No. 2 (September 2010):47.

${ }^{7}$ Badan Pusat Statistik Provinsi Gorontalo, "Kondisi Kemiskinan Provinsi Gorontalo Maret 2016," diakses 14 Maret 2017, http://gorontalo.bps.go.id/back7500/brs_ind/brsInd-20160718140928.pdf.

${ }^{8}$ Badan Pusat Statistik Provinsi Gorontalo, "Kondisi Kemiskinan Provinsi Gorontalo Maret 2016," diakses 14 Maret 2017, http://gorontalo.bps.go.id/back7500/brs_ind/brsInd-20160718140928.pdf. 
kesenjangan antara pelayanan gereja yang ditujukan untuk menjawab persoalan-persoalan sosial, budaya, politik, dan ekonomi dengan pelayanan untuk memenuhi kebutuhan pembinaan kerohanian/iman jemaat.

Fakta ini memang bisa saja tidak cukup memadai untuk menarik kesimpulan bahwa tidak ada kepedulian gereja terhadap persoalan kemiskinan dan ketidakadilan dalam masyarakat. Tidak dapat dipungkiri adanya aktivitas gereja yang menunjukkan keterlibatannya dalam upaya penanggulangan masalah kemiskinan. Sebagai contoh, sudah cukup banyak juga organisasi/denominasi gereja yang membangun sekolah-sekolah dan rumah sakit, mengadakan pembagian sembako bagi masyarakat yang kurang mampu, dan masih banyak lagi kegiatankegiatan sosial dan kemanusiaan karitatif lainnya dengan tujuan untuk membantu mengatasi persoalan kemiskinan dalam jemaat dan masyarakat kita. Kenyataan ini merupakan sebuah pertanda adanya kepedulian dan keterlibatan gereja.

Tulisan ini menyoroti suatu lokasi penelitian yaitu Gereja Protestan Indonesia di Gorontalo (GPIG). Apa pandangan teologi sosial GPIG terhadap realitas kemiskinan tersebut? Apakah GPIG sudah membangun refleksi teologis yang dapat dijadikan sebagai sumber inspirasi bagi warga gereja ikut berperan dalam penanggulangan masalah kemiskinan dan ketidakadilan sosial? Untuk menjawab pertanyaan tersebut, tulisan ini akan menghimpun dan menganalisis data yang bersumber dari pemikiran-pemikiran teologis, baik yang diartikulasikan oleh perorangan (pendeta, guru agama, penatua, diaken) maupun pemikiran teologis dan sikap GPIG sebagai satu lembaga agama sebagaimana yang dicerminkan dalam hasil-hasil persidangan dari tingkat jemaat hingga sinodal. Untuk menemukan makna yang lebih utuh dari dokumen gereja yang diinterpretasi tersebut, maka penelitian ini juga menghimpun data dari beberapa informan yang terlibat secara langsung dalam perumusan dokumen - dokumen gereja tersebut.

\section{Teologi Sosial Sebagai Teologi Kontekstual}

Di kalangan umat Kristen Protestan di Indonesia, istilah teologi sosial belum jamak digunakan dalam percakapan akademik maupun public. Sebagaimana yang diungkapkan oleh Julianus Mojau, istilah teologi sosial mulai sering digunakan ketika wacana civil society menjadi trending topic di kalangan umat Kristen Protestan di Indonesia sekitar tahun 2000. ${ }^{9}$

${ }^{9}$ Julianus Mojau, Meniadakan atau Merangkul : Pergulatan Teologis Protestan dengan Islam Politik di Indonesia (Jakarta: BPK Gunung Mulia, 2012), 8-11. 
Walau demikian, secara substansi, teologi sosial sesungguhnya sudah terkandung dalam dokumen resmi gereja dan lembaga-lembaga di kalangan umat Kristen Protestan. Hal ini nampak dalam dokumen resmi, dan tulisan-tulisan teologis perorangan yang merupakan respons umat Kristen Protestan di Indonesia terhadap dinamika kondisi sosial, politik, dan ekonomi di negara ini.

Dalam kajian historinya tentang keterlibatan Kekristenan Barat dalam upaya peningkatan kesejahteraan masyarakat dan pelayanan sosial, Nicholas Placido mengemukakan bahwa keterlibatan itu sangat melekat pada tradisi kekristenan Yahudi, sebagaimana yang diungkapkan dalam narasi Perjanjian Lama tentang kasih dan kepedulian terhadap sesama manusia. ${ }^{10}$

Di lingkungan Gereja Protestan Indonesia di Gorontalo, berdasarkan pengamatan penulis, istilah ini juga tidak akan kita temukan dalam dokumen-dokumen resmi GPIG. Namun dalam beberapa dokumen resmi yang peneliti telaah, substansi dari teologi sosial ada terkandung di dalam dokumen-dokumen resmi gereja tersebut. Kesimpulan ini berdasarkan pada pemberian arti dari istilah teologi sosial sebagaimana yang diungkapkan oleh Banawaritma dan Mueller, yang mengartikulasikan teologi sosial sebagai usaha dari orang-orang percaya dalam menghayati iman mereka dalam konteks sosial kemasyarakatan yang paling konkret di mana mereka hidup. ${ }^{11}$

Sehingga dengan demikian, teologi sosial selalu berpangkal pada pengalaman dan masalah manusia di tengah konteks kemasyarakatan yang nyata dengan berbagai segi kehidupannya, menuju penghayatan Injil yang lebih mendalam dalam situasi-situasi tersebut. Maka teologi sosial di satu pihak dapat disebut sebagai teologi kontekstual, dan juga teologi khusus tentang keterlibatan umat beriman dalam masalah-masalah sosial kemasyarakatan. ${ }^{12}$

Berdasarkan bingkai pemahaman tersebut, maka teologi sosial GPIG dalam tulisan ini diartikan sebagai refleksi teologi yang menggambarkan pemahaman GPIG tentang penghayatan iman Kristen dalam menanggapi masalah-masalah sosial ekonomi, khususnya terhadap realitas kemiskinan dan ketidakadilan sosial dalam masyarakat.

\footnotetext{
${ }^{10}$ Nicholas Placido, "A History of Charity and The Church", (Makalah yang dipresentasikan pada pertemuan North American Association of Christians in Social Work Convention November 2015), diakses 15 Februari 2017, http://www.nacsw.org/Convention/PlacidoNAHistoryFINAL.pdf.

${ }^{11}$ J. B. Banawiratma dan J. P. Müller, Berteologi Sosial Lintas Ilmu: Kemiskinan Sebagai Tantangan Hidup Beriman (Yogyakarta: Kanisius, 1993), 23.

${ }^{12}$ Julianus Mojau, Meniadakan atau Merangkul : Pergulatan Teologis Protestan dengan Islam Politik di Indonesia, 9.
} 


\section{Pergumulan Rangkap: Memahami Panggilan dan Pergumulan Gereja di Indonesia}

Bagaimana pemikiran teologis dan praksis gereja-gereja di Indonesia dalam menanggapi persoalan kemiskinan dalam masyarakat? Menjawab pertanyaan ini kita perlu untuk menelisik bagaimana keterlibatan gerejagereja dalam menjawab permasalahan-permasalahan yang mendera bangsa Indonesia dari masa kolonial hingga masa sekarang ini.

Tak dapat dipungkiri bahwa pada masa kolonial kekristenan merupakan agama yang diperkenalkan atau disyiarkan oleh bangsabangsa barat (Belanda dan Portugis) yang juga menghadirkan masa-masa kelam penjajahan bagi bangsa Indonesia. Akibatnya kekristenan (Protestan dan Katolik) di Indonesia cukup lama, bahkan mungkin hingga saat ini, masih sukar untuk "dibersihkan" dari persepsi sebagai agama asing, agama yang tidak nasionalis, atau agama warisan dari bangsa penjajah. ${ }^{13}$ Ini adalah "pil" pahit bagi gereja-gereja di Indonesia. Persepsi ini telah memposisikan kekristenan sebagai agama yang tidak menunjukkan keberpihakannya terhadap penderitaan, penindasan, dan ketidakadilan yang dialami oleh bangsa Indonesia pada masa kolonial bangsa barat.

Umat Kristen di Indonesia tidak sependapat bila kekristenan diidentikkan dengan kolonialisme atau imperialisme. Sama seperti umat muslim yang tidak akan sependapat bila Islam diidentikkan dengan terorisme. Meskipun demikian umat Kristen di Indonesia tidak menyangkal bahwa kekristenan dan kolonialisme hadir di Indonesia secara bersamaan dengan kedatangan bangsa-bangsa penjajah yang mayoritas rakyatnya beragama nasrani. Itu adalah fakta sejarah yang tidak dapat ditiadakan. Namun menyamakan Injil yang disaksikan atau diberitakan oleh paramisionaris bangsa Barat pada masa penjajahan dengan kolonialisme adalah suatu cara pandang yang sangat menyesatkan. Karena sejak dari awal keberadaan VOC di Indonesia adalah untuk kepentingan perdagangan bukan untuk penyebaran Injil. Sehingga tidaklah mengherankan bila terkadang VOC mengambil kebijakan-kebijakan yang bertolakbelakang dengan harapan dari gerejagereja atau lembaga-lembaga misi yang melaksanakan aktivitas misi di Indonesia. ${ }^{14}$

Situasi lain yang perlu untuk diperhatikan adalah berkembangnya paham pietisme ${ }^{15}$ yang disebarkan oleh para misionaris pada abad XIX.

${ }^{13}$ A. A. Yewangoe, Theologia Crusis Di Asia: Pandangan-Pandangan Orang Kristen Asia Mengenai Penderitaan Dalam Kemiskinan Dan Keberagamaan Di Asia, 290-291.

${ }^{14}$ Yewangoe, 290-291.

15 Pietisme merupakan suatu gerakan keagamaan yang menekankan pentingnya kesalehan hidup, ketaatan terhadap Alkitab, pertobatan, dan semangat penginjilan. 
Paham ini sangat menekankan pentingnya kesungguhan diri untuk mencapai perubahan hidup secara total (kelahiran kembali secara rohani dan keselamatan pribadi) dan kurang memberikan perhatian dan kepedulian terhadap persoalan-persoalan sosial, budaya, ekonomi, politik, dan berbagai bidang kehidupan masyarakat lainnya. Sehingga gereja-gereja yang sangat dipengaruhi oleh paham gerakan ini terkadang tidak cukup memiliki kerangka berpikir secara lintas ilmu untuk menyatakan pandangan dan keterlibatannya secara konkrit terhadap persoalan-persoalan dalam masyarakat, khususnya terhadap masalah kemiskinan dan ketidakadilan dalam masyarakat.

A. A. Yewanggoe dalam penjelasannya mengenai gereja dan masalah sosial pasca kemerdekaan mengungkapkan bahwa dirumuskannya beberapa pokok pikiran teologi dalam Konsultasi Teologi dan Pendidikan Teologi di Sukabumi, Jawa Barat pada tanggal 23-28 November 1970 merupakan suatu momentum penting bagi gereja-gereja di Indonesia (khususnya gereja-geraja anggota PGI) untuk meninjau kembali (lebih tepatnya bersikap kritis) warisan teologi pietisnya. ${ }^{16}$ Kegiatan konsultasi itu menghasilkan suatu pemikiran teologi yang lebih memadai bagi gereja-gereja di Indonesia untuk terlibat secara nyata menjawab persoalan-persoalan dalam masyarakat di berbagai bidang kehidupan. Hasil-hasil pemikiran dalam konsultasi itu kemudian dituangkan dalam laporan yang diberi nama "Pergumulan Rangkap". ${ }^{17}$

Salah satu pokok pikiran penting yang dihasilkan dalam konsultasi di Sukabumi tersebut adalah mengenai pemahaman tentang keselamatan yang lebih diperluas maknanya karena keselamatan dihubungkan dengan tema pembangunan. Paling tidak ada tiga pernyataan yang berbicara tentang perihal tersebut: ${ }^{18}$

Gerakan ini berlangsung antara akhir abad XVII hingga pertengahan abad XVIII, sebagai reaksi terhadap kondisi gereja di kalangan Lutheran yang ritual-ritualnya dipandang sangat formal dan mekanis. Sebagaimana yang diungkapkan oleh Leonard Hale dalam bukunya yang bertajuk Jujur Terhadap Pietisme: Menilai Kembali Reputasi Pietisme dalam Gereja-Gereja di Indonesia (Jakarta: BPK Gunung Mulia, 1993). Istilah pietisme pertama kali muncul dan populer di kalangan gereja Lutheran sekitar tahun 1677. Istilah ini ditujukan pertama kali pada sekelompok jemaat Lutheran yang hidup saleh (collegia peitatis). Dan bila kita menelaah latar belakang munculnya kelompok ini menurut penuturan Leonard Hale, maka kehadiran collegia peitatis merupakan suatu upaya untuk melakukan reformasi dalam jemaat dan masyarakat, khususnya di wilayah Jerman.

16 Yewangoe, 300-302.

17 Istilah "Pergumulan Rangkap" pertama kali diperkenalkan oleh Richard Niebuhr seorang teolog dari Amerika yang banyak menghasilkan pemikiran-pemikiran mengenai bagaimanakah hubungan antara iman Kristen dan kebudayaan. Salah satu bukunya yang popular di kalangan gereja-gereja di Indonesia adalah Christ and Culture.

${ }^{18}$ Yewangoe, 300-302. 
Pertama, adanya keterkaitan antara keselamatan dan sejarah. Dikemukakan bahwa keselamatan dikerjakan oleh Tuhan dalam sejarah manusia, di mana sejarah keselamatan itu merupakan suatu proses penaklukan kuasa-kuasa kegelapan atau kejahatan yang masih sementara terus bergerak menuju pada penggenapannya (1 Kor. 15:28; Kol. 1:20; Why. 21:5)

Kedua, oleh karena diyakini bahwa Allah bekerja dalam sejarah maka pembangunan bukanlah suatu jaminan bagi terciptanya perdamaian, keselamatan, dan kesejahteraan. Karena sejarah menyatakan dirinya bukan sebagai peristiwa yang dapat dipastikan bergerak secara progresif kepada pengenapan penaklukankuasa-kuasa kejahatan. Kenyataan ini menuntut gereja-gereja untuk ikut serta berjuang agar tanda-tanda perdamaian, keselamatan, dan kesejahteraan tampak nyata dalam pembangunan pada setiap momentum sejarah yang menentukan keberadaan manusia dan masyarakat.

Ketiga, keselamatan hanya diperuntukkan bagi manusia karena itu hanya pada manusia ada tanggungjawab menjadi rekan sekerja Allah untuk mengelola alam agar menunjukkan tanda-tanda kemuliaan Allah

Dari beberapa pernyataan teologis tersebut, maka dapat disimpulkan bahwa konsultasi itu menegaskan pentingnya gereja-gereja di Indonesia untuk menyadari bahwa keselamatan sebagai salah satu dogma fundamental dalam iman Kristen dapat juga berbicara tentang pembangunan yang seharusnya sejalan dengan apa yang menjadi rancangan keselamatan Allah bagi manusia yang dikerjakan oleh Tuhan dalam sejarah kehidupan manusia dari satu peristiwa ke peristiwa selanjutnya.

Membaca beberapa pemikiran utama dari kegiatan konsultasi di Sukabumi tahun 1970 di atas, maka kurang tepat bila disimpulkan bahwa tak ada kesadaran gereja-gereja yang terlibat di dalamnya untuk "menyentuh" aspek kebobrokan struktural yang mengakibatkan ketidakadilan dan kemiskinan dalam masyarakat. Hal ini karena adanya gagasan tentang keselamatan sebagai sejarah penaklukan "kuasa-kuasa" kejahatan yang merampas hak-hak manusia untuk memperoleh kehidupan yang damai, berkeadilan dan sejahtera. Dan pembangunan bukanlah suatu jaminan bagi terwujudnya sejarah penaklukan tersebut. Oleh karena itu, gereja - gereja dituntut untuk memperjuangkannya supaya tanda-tanda Kerajaan Allah dapat dinyatakan dalam sejarah kehidupan umat manusia di belahan dunia manapun.

Lebih jelasnya, J. L. Ch. Abineno, menafsirkan bahwa karya pembebasan Allah dalam Alkitab adalah keselamatan atau shalom yang tidak dapat menjadi kenyataan bila tanpa keadilan (Yes. 32:17). ${ }^{19}$ Berdasarkan

${ }^{19}$ Yewangoe, 316. 
penafsiran tersebut, maka keselamatan atau shalom dapat diartikan sebagai situasi di mana keadilan bagi yang lemah, kemerdekaan bagi yang tertindas, dan dihapuskannya segala bentuk penindasan dari muka bumi ini. Semuanya bukanlah realitas rohani atau batiniah, melainkan realitas sosial politik, yang membawa serta suatu pembebasan dalam realitas sejarah manusia. James Ndyabahika lebih lanjut mengungkapkan makna shalom sebagai berikut.

Shalom involves communal harmonious economy; social, political and religious order; new life found in the feeding of the needy, the hungry, the refugees, widows, widowers and orphans. The poor within the parameters of shalom obtain justice and are delivered from economic injustices. ${ }^{20}$

Komunitas Shalom terdiri atas komunitas harmonis dalam segala aspek (ekonomi, sosial dan politik) yang memerhatikan kepentingan orang miskin (termasuk memberi makan orang miskin, yang lapar, para pengungsi, janda, para janda anak yatim) dan menegakkan keadilan sosial di bidang ekonomi.

Kemiskinan Asia dan perjuangan untuk hidup merupakan seruan bagi gereja-gereja Asia dan teologi Kristen untuk kembali pada aspirasiaspirasi dasar dari Kekristenan dalam Kitab Suci, hidup Yesus, dan gereja mula-mula, yang sangat memedulikan hidup manusia dan keadilan..$^{21}$ Gereja selalu bergumul dengan dunia di mana ia diutus. Gereja bergumul dengan teks dan konteksnya, sehingga gereja tetap menjalankan fungsinya menjadi garam dan terang bagi dunia. ${ }^{22}$

Dalam komunitas Kristen yang setia, shalom harus menyertakan perbuatan memberikan makanan kepada orang yang lapar, memulihkan penglihatan orang buta, menyembuhkan orang sakit, pemberian keadilan bagi para tahanan, memaafkan orang-orang berdosa, pemberian kemerdekaan bagi yang tertindas dan memberitakan kabar baik kepada sesama ( Luk 4:18-19;7:22). Untuk mencari dan mengejar shalom adalah dengan terlibat terus dalam perjuangan untuk kasih, kebaikan, kehormatan, kesejahteraan dan keadilan. Meskipun shalom melampaui

${ }^{20}$ James Ndyabahika, "Biblical Economy, Wealth And Poverty: A Challenge To The Great Lakes Region Of East Africa," McMaster Journal of Theology and Ministry 8 (2007):72.

${ }^{21}$ Yunus D. A. Laukapitang, "Teologi Pembangunan Berbasis Pengembangan Masyarakat Shalom Pada Gereja Kemah Injil Indonesia Daerah Kupang Nusa Tenggara Timur," Jurnal Jaffray 14, No. 2 (Oktober 2016):243; kutipan dari Tissa Balasuriya, Teologi Siarah (Jakarta: BPK Gunung Mulia, 1994), 150.

${ }^{22}$ Yunus D. A. Laukapitang, "Teologi Pembangunan Berbasis Pengembangan Masyarakat Shalom Pada Gereja Kemah Injil Indonesia Daerah Kupang Nusa Tenggara Timur," Jurnal Jaffray 14, No. 2 (Oktober 2016):243. 
keadilan, tetapi tidak bisa ada shalom tanpa keadilan, karena dalam shalom, manusia mengalami dan menikmati keadilan. ${ }^{23}$ Gereja hadir untuk mewujudkan gambar Allah melalui komunitas masyarakat shalom yang memberdayakan jemaat Tuhan untuk dapat memberdayakan kaum miskin untuk mewujudkan keadilan sosial.

\section{Peran Gereja Terhadap Kemiskinan}

Gereja ada di tengah-tengah dunia ini dengan tujuan melayani mereka yang miskin dan menderita. ${ }^{24}$ Kemiskinan adalah fakta kehidupan sekalipun ada perbaikan ekonomi namun kenyataannya terjadi kemerosotan ekonomi yang berujung pada peningkatan kemiskinan. Yesus mengatakan bahwa "orang-orang miskin akan selalu berada dengan kamu ... " (Mat. 26:1l, NIV) dan kenyataan historis dan masih relevan secara global. ${ }^{25}$ Dengan demikian gereja hadir untuk memerhatikan mereka sebagai bagian dari kehidupan bergereja sebab mereka selalu ada di sekitar komunitas orang percaya.

Kesadaran gereja untuk mendahulukan kaum miskin yang tidak berdaya, berarti juga memperjuangkan keadilan, perdamaian dan keutuhan ciptaan dan merupakan wujud kesetiaan pada Yesus Kristus. ${ }^{26}$ Gereja hadir untuk berperan sebagai Kristus di muka bumi untuk meyatakan kemanusiaan-Nya dengan memperjuangkan keadilan sosial bagi kaum miskin.

Orang-orang miskin dalam kitab PL maupun PB memperlihatkan bahwa (a) kaum miskin bukan ditentukan oleh sifat religius mereka tetapi lebih disebabkan kemiskinan fisik, (b) Kaum miskin dalam Alkitab juga merupakan kaum dialektis yang disebabkan oleh kelompok-kelompok yang bertindak tidak adil dan menyingkirkan mereka, dan (c) Kaum miskin

${ }^{23}$ James Ndyabahika, "Biblical Economy, Wealth And Poverty: A Challenge To The Great Lakes Region Of East Africa," McMaster Journal of Theology and Ministry 8 (2007):72. Terjemahan oleh penulis.

${ }^{24}$ Yunelis Ndraha, "Kaum Miskin Ada Di Antaramu: Pemberdayaan Jemaat Pasca Gempa Bumi di Distrik BNKP Awa'ai,” (Thesis Master, Duta Wacana Christian University, 2008), 1; Yunelius Ndhara mengutip pernyataan Emanuel Gerrit Singgih, Reformasi dan Transformasi Pelayanan Gereja Menyongsong Abad ke-2l (Yogyakarta, Kanisius, 1997), 27.

${ }^{25}$ Adewunmiju, dan Peter Olutayo, "A Biblical Approach and Response to Poverty," diakses 15 Februari 2017, http://www.biblicaltheology.com/Research/AdewunmijuPO0l.pdf.

${ }^{26}$ Suroso, "Mendahulukan Kaum Miskin Refleksi Sosial Dan Teologis Kontekstualiasi Dalam Bergereja," 3, diakses 15 Februari 2017, http:/staff.uny.ac.id/sites/default/files/PERANG\%20TERHADAP\%20KEMISKINAN.p df. 
dalam Kitab Suci adalah kelompok dinamis. Mereka bukan korban-korban pasif dalam sejarah. Melalui dan bersama mereka, Allah membentuk sejarahNya. ${ }^{27}$

Gereja bertanggung jawab terhadap kaum miskin, orang yang terabaikan sebagai suatu sikap mengasihi sesama dan wujud nyata kasih Tuhan kepada orang percaya dan diberikan pula kepada orang-orang miskin.

Kemiskinan memengaruhi berbagai aspek kehidupan masyarakat, ada ketika orang tidak diberi kesempatan untuk bekerja, belajar, hidup sehat dan kebutuhan, dan menjalani masa pensiun mereka dalam keamanan. Kurangnya pendapatan, akses kesehatan, kualitas pendidikan yang baik dan perumahan, dan kualitas lingkungan setempat semua memengaruhi kesejahteraannya. ${ }^{28}$

Gereja tidak boleh melupakan perannya dalam kehidupan bermasyarakat. Oleh karena itu gereja berdoa dan bertindak bagi kesejahteraan kotanya termasuk di dalamnya adalah berdampak bagi kaum miskin dan orang-orang yang terabaikan dan secara sosial tidak mendapatkan keadilan. Hal ini akan dibahas secara khusus tentang "teologi sosial" GPIG.

\section{Qua Vadis Teologi Sosial GPIG}

Untuk dapat menemukan gambaran tentang bagaimana teologi sosial yang berkembang di GPIG $^{29}$ menanggapi kondisi kemiskinan

${ }^{27}$ Suroso, "Mendahulukan Kaum Miskin Refleksi Sosial Dan Teologis Kontekstualiasi Dalam Bergereja," 3, diakses 15 Februari 2017, http://staff.uny.ac.id/sites/default/files/PERANG\%20TERHADAP\%20KEMISKINAN.p df; Suroso mengutip pernyataan Banawiratma, 10 Agenda Pastoral Transformatif: menuju Pemberdayaan Kaum Miskin dengan Perspektif Adil Gender, HAM, dan Lingkungan Hidup (Yogyakarta: Kanisius, 2002), 22.

${ }^{28}$ David Gordon, "The Concept And Measurement Of Poverty," dalam Poverty and Social Exclusion in Britain, ed. C. Pantazis, D. Gordon, and R. Levitas (Bristol, The Policy Press, 2006), 30.

29 Sejarah menerangkan bahwa terhitung mulai tanggal 18 Desember 1964, Gereja Protestan Indonesia di Gorontalo telah berdiri sendiri dan terpisah secara organisasi dengan GMIM. Karena pada tanggal tersebut, dalam acara penutupan Sidang Sinode GMIM, GPIG diresmikan sebagai Gereja Bagian Mandiri dari Gereja Protestan Indonesia di Indonesia (GPI) bersama dengan dua gereja lainnya yang sebelumnya merupakan bagian yang tak terpisahkan dari Gereja Masehi Indonesia Minahasa (kedua organisasi gereja lain tersebut adalah Gereja Protestan Indonesia Donggala dan Gereja Protestan Indonesia Buol Toli-Toli). Selanjutnya dicatat dalam sejarah GPIG, peresmian GPIG dilaksanakan di Gorontalo pada tanggal 18 Juli 1965 yang dihadiri oleh jemaat, gereja-gereja yang ada di Provinsi Gorontalo, Pemerintah Kota Praja (KOPRA) DATI II Gorontalo, dan masyarakat Gorontalo lainnya. Tanggal tersebutlah yang 
dalam jemaat dan masyarakat maka ada beberapa pokok pikiran teologi yang perlu dicermati di GPIG. Bila mengacu pada tulisan di atas tentang "pergumulan rangkap", maka pemahaman GPIG tentang keselamatan dan bagaimana pemahaman tersebut bila dikaitkan dengan pembangunan dan ketidakadilan dalam masyarakat diharapkan akan memberikan pencerahan seperti apakah teologi sosial yang telah dan sedang berkembang di GPIG dalam menanggapi masalah kemiskinan.

Dalam pembukaan Tata Dasar GPIG alinea pertama dikatakan bahwa GPIG merupakan persekutuan orang percaya yang terbentuk karena karya Allah Tritunggal dengan tujuan untuk mewujudkan kehendak dan kasih karunia Allah bagi keselamatan dunia. ${ }^{30}$ Berdasarkan alinea yang pertama ini kita dapat simpulkan bahwa tujuan dari keberadaan GPIG adalah untuk mewujudnyatakan kasih karunia Allah yang menyelamatkan dunia. Namun bagaimana pemahaman GPIG tentang kasih karunia Allah yang menyelamatkan dunia itu tidak diberi penjelasan lebih lanjut.

Menurut penjelasan dari Pdt. Jemi Paulus Bambung sebagai salah satu konseptor Tata Dasar Gereja GPIG tahun 2010, konsep keselamatan yang dimaksudkan dalam alinea pertama Tata Dasar Gereja GPIG tersebut tidak dapat dipisahkan dari pemahaman tentang kebinasaan manusia akibat dari dosa. ${ }^{31}$ Jadi keselamatan dalam hal ini adalah kasih karunia Allah yang membebaskan manusia dari kebinasaan akibat dari dosa. Namun tidak sebatas itu saja, lebih lanjut diungkapkan oleh Pdt. Jemi P. Bambung, bahwa makna keselamatan yang terkandung dalam Tata Dasar Gereja itu juga bersifat holistik, utuh. Artinya bahwa GPIG berdasarkan Tata Dasar Gereja tahun 2010 itu menganut pemahaman tentang keselamatan yang tidak hanya meyakini keselamatan yang dikerjakan oleh Allah itu hanya untuk membebaskan manusia dari penghukuman akibat dosa tetapi juga keselamatan sebagai karya Allah yang membebaskan manusia dari segala akibat dari dosa yakni

kemudian ditetapkan sebagai hari berdirinya Sinode GPIG, yang kemudian diperingati

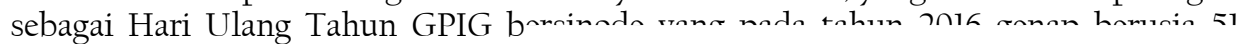
tahun.Berdasarkan data statistik yang ada, Gereja Prostestan Indonesia di Gorontalo terdiri dari 69 (enam puluh sembilan) jemaat yang tersebar di 10 (sepuluh) wilayah pelayanan dengan jumlah jiwa diperkirakan sekitar 12.000 (dua belas ribu) jiwa. Seluruh jemaat berada di Provinsi Gorontalo yang tersebar di l (satu) wilayah kotamadya yakni Kota Gorontalo dan 5 (lima) kabupaten yakni Gorontalo, Gorontalo Utara, Bone Bolango, Boalemo, dan Pohuwato. Adanya GPIG di Provinsi Gorontalo merupakan hasil pekabaran Injil dari NZG yang merupakan bagian dari jemaat dan misi Pekabaran Injil dari gereja aliran Calvinis di negeri Belanda; Yusak Soleiman, Sejarah Gereja Protestan di Indonesia, Jilid 2 (Jakarta: BPK Gunung Mulia, 2015), 197.

${ }^{30}$ Tata Gereja Protestan Indonesia di Gorontalo tahun 2010.

${ }^{31}$ Pendeta Jemi P. Bambang, Wawancara oleh Penulis, Gorontalo, 10 Februari 2017. 
ketidakadilan, penindasan, penderitaan dalam berbagai bidang kehidupan sehingga dengan demikian memungkinkan bagi manusia untuk menikmati keselamatan, shalom, damai dan sejahtera Tuhan itu secara utuh.

Paul F. Knitter dalam usahanya membangun suatu dialog antar umat beragama dalam konteks masyarakat di era globalisasi mengungkapkan bahwa masa depan dialog antara umat beragama di era globalisasi sekarang ini sangat bergantung salah satunya pada kesadaran dari tiap agama mengambil tanggung jawab membebaskan manusia dan planet ini dari penderitaan. Pembebasan itulah yang disebut sebagai soteria oleh Paul F. Knitter, yakni kesejahteraan bagi manusia (humanum) dan lingkungan (cosmicum). Pandangan ini merupakan suatu pemikiran teologis yang memperluas makna dari keselamatan (soteria) bukan hanya sebatas dibebaskannya manusia dari penderitaan akibat dari keberdosa-an manusia. ${ }^{32}$

Namun berdasarkan pengamatan penulis sebagai jemaat dan pelayan khusus di GPIG, pemahaman tentang keselamatan sebagaimana yang terkandung dalam Tata Dasar Gereja GPIG masih belum dimanifestasikan secara maksimal oleh jemaat GPIG. Faktanya bahwa hanya sebagian kecil saja jemaat di lingkungan GPIG yang telah merencanakan dan melaksanakan panggilan dan tugas gereja dengan maksud dan tujuan untuk membantu peningkatan kesejahteraan jemaat dan masyarakat di bidang ekonomi atau bidang kehidupan lainnya. Kegiatan pemberdayaan ekonomi jemaat dan masyarakat belum menjadi salah satu program yang diprioritaskan. Program semacam itu terkadang hanya sebagai program sampingan dan tidak dilaksanakan secara sistematis dan berkelanjutan. Penulis mengamati bahwa hampir sebagian besar jemaat masih terbenam dengan panggilan dan tugas gereja untuk melaksanakan Sakramen Kudus, diakonia duka dan sakit, katekisasi, dan tugas gereja lainnya yang bersifat ritual/peribadatan.

Walaupun demikian pada tataran refleksi, kesadaran tentang keselamatan yang utuh sudah mulai berkembang dengan baik. Di kalangan pelayan khusus (Pendeta, Penatua, Diaken, dan Guru Agama), interpretasi tentang keselamatan yang lebih diperluas pemaknaannya mulai bertumbuh dengan adanya upaya kemandirian dalam teologi dan daya melalui program pendidikan sarjana teologi dan keikutsertaan pelayan khusus mengikuti kegiatan seminar/workshop yang mengangkat tema-tema dialog antar umat beragama dan pelestarian lingkungan hidup. Namun keikutsertaan tersebut belum efektif membentuk kesadaran jemaat tentang keselamatan bagi kesejahteran manusia dan

32 Paul F. Knitter. Satu Bumi Banyak Agama: Dialog Multi Agama dan Tanggung Jawab Global (Jakarta: BPK Gunung Mulia, 2006), 52-53. 
lingkungan karena terkendala keterbatasan mendesiminasikan pemikiran dan praksis yang diperoleh dalam kegiatan tersebut.

Bila melihat pada dokumen Tata Dasar GPIG, keterlibatan GPIG membebaskan manusia dari penderitaan kemiskinan dan ketidakadilan dalam masyarakat bersumber dari ketetapan GPIG mengenai panggilan dan tugas GPIG. Pokok panggilan dan tugas itu dikatakan dalam:

1. Pembukaan Tata Dasar Gereja GPIG

2. Tata Dasar Gereja GPIG Bab V tentang Penyelenggaraan dan Tugas Panggilan pada Pasal 10 tentang Tugas Panggilan GPIG

3. Peraturan GPIG Nomor: 01 Tahun 2010 tentang Jemaat Bab II pada pasal 5 yang menjelaskan tentang Pokok-Pokok Panggilan Jemaat.

Mengacu pada Pembukaan Tata Dasar Gereja GPIG, panggilan dan tugas utama GPIG tidak lain daripada melaksanakan amanat Yesus Kristus yakni memberitakan perbuatan-perbuatan baik dari Allah dengan melaksanakan pemberitaan firman Allah, pelayanan sakramen, pelayanan kasih, kebenaran dan keadilan, serta usaha lainnya yang sejalan dengan amanat Yesus Kristus. Pokok panggilan dan tugas tersebut yang sangat mendukung bagi arah hidup gereja yang berjuang bagi upaya membebaskan manusia dari penderitaan akibat kemiskinan dan ketidakadilan sosial adalah melaksanakan pelayanan kasih, kebenaran dan keadilan. Menurut penjelasan dari Pendeta Juanita Takasenseran,

Panggilan untuk melaksanakan pelayanan kasih dalam Pembukaan Tata Gereja GPIG merupakan suatu pernyataan teologis yang mengungkapkan tentang adanya tanggung jawab GPIG untuk menyatakan kasih melalui tindakan menolong jemaat dan masyarakat yang mengalami penderitaan karena penyakit, bencana, kemiskinan, dan lain-lain. Panggilan ini sebagai bagian dari upaya gereja untuk mewujudnyatakan kasih Allah yang menyelamatkan dunia. ${ }^{33}$

Sedangkan panggilan untuk menegakkan kebenaran dan keadilan, menurut penjelasan dari Pdt. Jemi Paulus Bambung, dilatarbelakangi oleh kesadaran GPIG bahwa sekalipun tugas utama gereja di dunia adalah memberitakan Injil, melaksanakan Sakramen, ibadah, katekisasi, Pendidikan Agama Kristen, Pembinaan Warga Gereja dan pelayanan diakonia, GPIG juga terpanggil untuk menyatakan keyakinan pada Kristus sebagai Tuhan dan Juruselamat yang memperjuangkan berdaulatnya Kerajaan Allah di tengah-tengah kehidupan manusia. ${ }^{34}$

\footnotetext{
${ }^{33}$ Pendeta Juanita Takasenseran, Wawancara Oleh Penulis, Gorontalo, 10 Februari 2017.

${ }^{34}$ Pendeta Jemi P. Bambang, Wawancara oleh Penulis, Gorontalo, 10 Februari 2017.
} 
Dari hasil wawancara dengan beberapa pelayan khusus (Pendeta, Penatua, Guru Agama, Diaken) di lingkungan GPIG, ditemukan bahwa hampir sebagian besar yang telah memahami Kerajaan Allah sebagai suatu konsep teologis yang tidak terpisahkan dari perjuangan menegakkan kebenaran, keadilan dan keberpihakan pada yang tertindas dalam suatu sistim sosial.

Dengan demikian dapat ditarik suatu kesimpulan bahwa di masukkannya pelayanan kasih, kebenaran dan keadilan sebagai bagian dari penyelenggaraan Amanat Yesus Kristus, serta panggilan dan tugas GPIG merupakan suatu ungkapan teologis yang menunjukkan adanya kesadaran ekslesiologi GPIG tentang gereja sebagai persekutuan orangorang percaya yang terpanggil untuk terlibat dalam perjuangan membebaskan manusia dari penderitaan karena kemiskinan dan ketidakadilan dalam suatu sistem sosial. Pemahaman ini bersesuaian dengan penafsiran tentang keselamatan sebagai karya pembebasan Allah yang bertujuan untuk menghadirkan shalom ditengah-tengah kehidupan manusia, yang mana tidak mungkin tercapai tanpa keadilan. Sehingga dalam kerangka pemikiran tersebut, shalom itu berarti ditegakkannya keadilan bagi yang lemah dan dihapuskannya segala bentuk penindasan di atas muka bumi ini.

Kesadaran ekslesiologi GPIG tentang gereja sebagai persekutuan orang-orang percaya yang terpanggil untuk terlibat dalam perjuangan membebaskan manusia dari penderitaan karena kemiskinan dan ketidakadilan dalam suatu sistem sosial lebih diperkuat lagi dengan ditetapkannya tentang Tugas Panggilan GPIG dalam Tata Dasar Gereja GPIG Bab V, Pasal 10 serta ketetapan tentang Pokok-Pokok Panggilan Jemaat dalam Peraturan GPIG Nomor: 01 Tahun 2010, Bab II, Pasal 5. Kedua ketetapan gereja tersebut memiliki substansi yang sama yakni menetapkan apa yang menjadi panggilan dan tugas GPIG, yang di dalamnya tercantum pelayanan untuk mencapai keutuhan ciptaan, perdamaian, dan keadilan sebagai bagian dari panggilan dan tugas GPIG.

\section{Kesimpulan}

Untuk mendapatkan gambaran teologi sosial Gereja Protestan Indonesia di Gorontalo dalam menanggapi realitas kemiskinan dan ketidakadilan sosial, tulisan ini menjajakinya dengan menelaah pemahaman teologi GPIG mengenai keselamatan dan ketetapan GPIG tentang pokok panggilan dan tugas GPIG.

Berdasarkan data yang diperoleh, refleksi teologis yang tentang keselamatan yang terdapat dalam Tata Dasar Gereja GPIG tahun 2010 telah menganut pemahaman tentang keselamatan yang utuh. Namun pandangan tersebut masih belum direalisasikan secara maksimal dalam 
pelaksanaan tugas dan panggilan jemaat yang ada di lingkungan Gereja Prostestan Indonesia di Gorontalo.

GPIG memiliki beberapa memiliki acuan refleksi teologis yang dapat mendasari penghayatan gereja untuk berjuang menciptakan kesejahteraan bagi manusia dengan membebaskan manusia dari kemiskinan dan ketidakadilan sosial. Adanya ketetapan tentang pelayanan kasih, keutuhan ciptaan, perdamaian, kebenaran dan keadilan sebagai bagian dari pokok panggilan dan tugas Gereja Protestan Indonesia di Gorontalo dalam Tata Gereja Protestan Indonesia di Gorontalo menunjukkan sudah adanya sumber legitimasi secara organisasi untuk mengembangkan pemikiran teologi dan praksis eklesiologi GPIG yang ikut terlibat dalam upaya bersama menciptakan kesejahteraan bagi manusia dan lingkungan.

\section{Kepustakaan}

Buku-buku

Agusta, Ivanovich. Diskursus, Kekuasaan dan Praktik Kemiskinan di Pedesaan Jakarta: Yayasan Pustaka Obor Indonesia, 2014.

Banawiratma. 10 Agenda Pastoral Transformatif: menuju Pemberdayaan Kaum Miskin dengan Perspektif Adil Gender, HAM, dan Lingkungan Hidup. Yogyakarta: Kanisius, 2002.

Balasuriya, T. Teologi Siarah. Jakarta: BPK Gunung Mulia, 1994.

Bevans, Stephen B. Model-Model Teologi Kontekstual. Maumere. Flores: Ledalero, 2002).

Knitter, Paul F. Satu Bumi Banyak Agama : Dialog Multi Agama dan Tanggung Jawab Global. Jakarta: BPK Gunung Mulia, 2006.

Howard, Roy J. Pengantar Atas Teori-Teori Pemahaman Kontemporer: Hermeneutika; Wacana Analitik, Psikososial, dan Ontologis. Bandung: Penerbit Nuansa, 2000.

Laukapitang, Yunus D. A. "Teologi Pembangunan Berbasis

Pengembangan Masyarakat Shalom Pada Gereja Kemah Injil Indonesia Daerah Kupang Nusa Tenggara Timur." Jurnal Jaffray 14, No. 2 (Oktober 2016):241-268.

Mojau, Julianus. Meniadakan atau Merangkul : Pergulatan Teologis Protestan dengan Islam Politik di Indonesia. Jakarta: BPK Gunung Mulia, 2012.

Ndraha, Y. "Kaum Miskin Ada Di Antaramu: Pemberdayaan Jemaat Pasca Gempa Bumi di Distrik BNKP Awa'ai." Thesis Master, Duta Wacana Christian University, 2008. 
Ndyabahika, J. "Biblical Economy, Wealth And Poverty: A Challenge To The Great Lakes Region Of East Africa." McMaster Journal of Theology and Ministry 8 (2007):64-81.

Pantazis, C., D. Gordon, and R. Levitas. Ed. Poverty and Social Exclusion in Britain, Bristol, The Policy Press, 2006.

Pantazis, C., D. Gordon, and R. Levitas. Ed. Poverty and Social Exclusion in Britain, Bristol, The Policy Press, 2006.

Placido, Nicholas Placido. "A History of Charity and The Church", North American Association of Christians in Social Work Convention. November 2015.

Singgih, Emanuel G. Reformasi dan Transformasi Pelayanan Gereja Menyongsong Abad ke-2l. Yogyakarta, Kanisius, 1997.

Soleiman, Yusak. Sejarah Gereja Protestan di Indonesia, Jilid 2. Jakarta: BPK Gunung Mulia, 2015.

Tata Dasar Gereja Protestan Indonesia di Gorontalo tahun 2010

Yewangoe, A. A. Theologia Crusis Di Asia Pandangan-Pandangan Orang Kristen Asia Mengenai Penderitaan Dalam Kemiskinan Dan Keberagamaan Di Asia. Jakarta: BPK Gunung Mulia, 2004.

Artikel Online

Adewunmiju, dan Peter Olutayo, "A Biblical Approach and Response to Poverty." Diakses 15 Februari

2017.http://www.biblicaltheology.com/Research/AdewunmijuPO01. pdf.

Suroso. "Mendahulukan Kaum Miskin Refleksi Sosial Dan Teologis Kontekstualiasi Dalam Bergereja." Diakses 15 Februari 2017. http://staff.uny.ac.id/sites/default/files/PERANG\%20TERHADAP\% 20KEMISKINAN.pdf.

Wawancara

Bambang, Jemi P. Wawancara oleh Penulis.Gorontalo, 10 Februari 2017.

Takasenseran, J. Wawancara Oleh Penulis.Gorontalo, 10 Februari 2017. 